$\mathrm{Oz}$

$1-1-1990$

\title{
Project for the Architecture of Transition
}

Leslie Buerk

Daniel Herr

Karl Puljak

Follow this and additional works at: https://newprairiepress.org/oz

\section{c) (i) $\Theta \Theta$}

This work is licensed under a Creative Commons Attribution-Noncommercial-No Derivative Works 4.0 License.

\section{Recommended Citation}

Buerk, Leslie; Herr, Daniel; and Puljak, Karl (1990) "Project for the Architecture of Transition," Oz: Vol. 12. https://doi.org/10.4148/2378-5853.1204

This Article is brought to you for free and open access by New Prairie Press. It has been accepted for inclusion in Oz by an authorized administrator of New Prairie Press. For more information, please contact cads@k-state.edu. 


\section{Project for the Architecture of Transition}

\author{
Leslie Buerk \\ Daniel Herr \\ Karl Puljak
}

Critic: Vladimir Krstic
Like birth, death retains its unknowability ... Incomplete as any work of art, death exists for the living as something profoundly invisible which we cannot make visible. The moment. All we have to work with are fragments, hints, clues to give the imagination room to create, to restore.

\section{David Meltzer}

Death as a subject of architecture is the art of the depiction of the invisible. It transgresses the field of architectural signification delineated by utility and purpose and imposes an unavoidable need to examine and question expressive limits of architecture. The absence of a precise (definable) content invalidates common architectural discourse - the metaphysical subject of death remains only approachable through the capacity to probe into the nature of architectural elements beyond the canonical preconceptions and seek intrinsic conditions of architecture in which the invisible becomes a silent counterpart of its physical presence. Death, thus, inscribes the annihilating territory of the unknown in the context of which the meaningful proposition of architecture can be sustained exclusively through the analytical reconstruction of its elementary condition.

The intention of the design exercise was to explore a different condition of architecture in which rational detertminants are rendered tentative (by displacing the actual design subject from the domain of vide a plausible resolution, the very idea of architecture had to be put to question and accordingly reconfigured pointing towards the realization of its more intrinsic aspects. Hence, the cemetery project. The topology of the project was defined by the two problematic extremes: funerary architecture as an instrument of celebration of death; and funerary architecture as a means of inquiry into the idea of antithetical world and the aspects of its phenomenal depiction and representation.

\section{Daniel Herr}

\section{PROCESSION}

downhill toward the west

through corridors

of shadows and light

\section{TRANSITION}

series of layered spaces

experiential qualities of the journey

the experience of death

BEGIN THE JOURNEY Procession begins at the top of a hill where columbariums (monuments to the dead) are placed, and then into a wall (corridor) which leads down the hill and to the west.

\section{FOCUS}

toward the west

symbolic notion of an end

WALK Compression of space within the wall creates a strong focus on the west the direction of the setting sun.

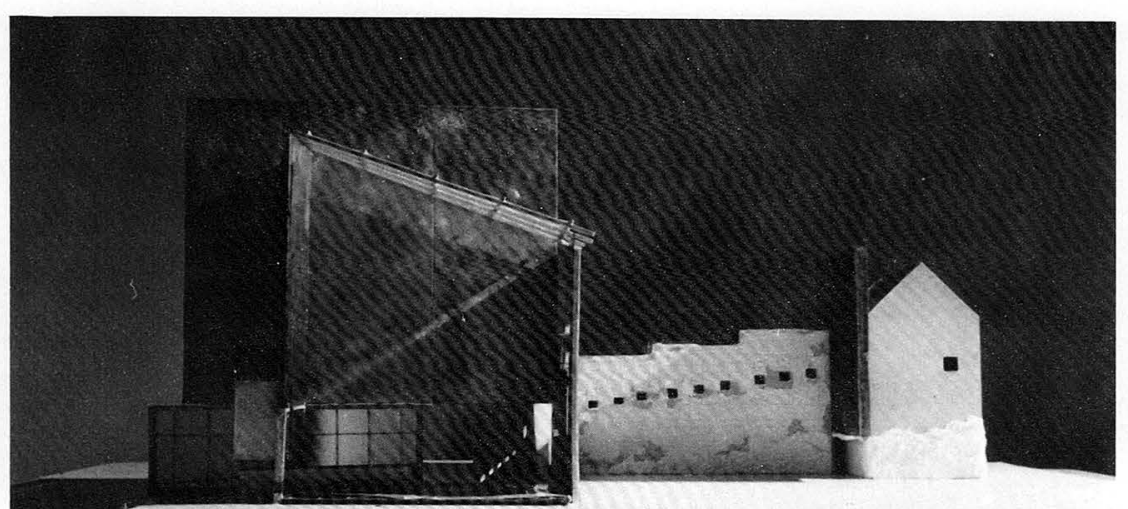

\section{REMORSE}

shadows ... traveling west ... down

\section{LAYERS}

space, shadows, understanding - experience to accommodate different participants of the ceremony: intimate friends, family, acquaintances ... death

ARRIVE Intimate friends and relatives first enter a place to meditate before the ceremony. The rest of the participants continue into a courtyard. The courtyard is filled with shadows.

\section{CHAOS}

deterioration and disorientation of chapel elements

walls
light
space
materials

FOREBODING The courtyard of shadows is violated, interrupted - by a wall which floats above the ground. The wall's position, orientation, and material indicate hostility. The procession con tinues beneath the wall. Into the place of death. the chapel is perceived to be temporary. This is not a place to dwell, but a resting point on a journey - the beginning and the end. Light, air, moisture enter gaps created by walls which do no join. The final realization of death's claim occurs in this place.

YEARNING The final view from inside the chapel is through a window which is focused on the crematorium at the bottom of the hill (to the west). The window serves as a doorway, suspended in the air, providing access to the pathway that the deceased will begin his new journey upon.
CONFRONTATION The structure of 


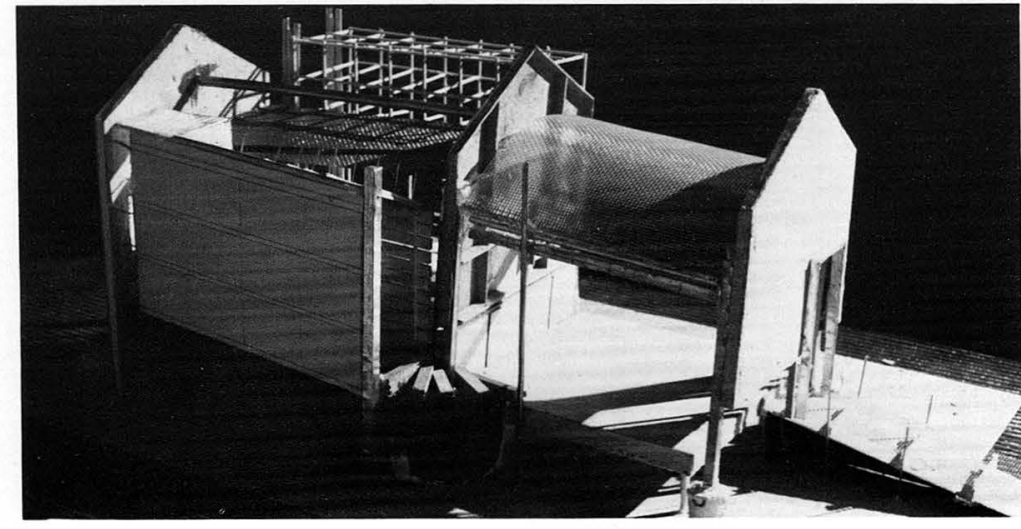

Karl Puljak

everything emanates from the Still Point primal moment both known and unknown that which is and that which is to be

evolution

linear time

ongoing

irrepressible time

pulls away

from the Still Point

complexity

man

shepherd

deciphers

attempts

orients himself

aspires reunification

to the Still Point

misinterpretation

subjectivity

man misunderstands

fragments

reunification

to Still Point

proves futile

linear time

relentless complexity

culminates

Death

sheds subjectivity

reunification

with the Still Point

\section{Leslie Buerk}

After presenting this exploration to my peers, I succumbed to a compelling desire to destroy a large portion of the presentation. I later realized why this unexpected act seemed necessary. The consequence of the destruction strengthened an interesting point fundamental to the project and to the concept of cemetery. Does physical loss make the impact of an existence - whether in the form of a set of ideas or an independent consciousness - any less significant? The destruction of the physical form, or the absence of the object itself, leaves us to consider its fundamental make-up: a set of ideas that led to the creation of a project, influenced its development, and led to its destruction. Perhaps it could be said that the real substance of the existence - the impact it has made on other existences - receives more attention after the demise of the concrete image. The absence of form allows us to investigate the spirit of the project and the conflicts from which it has arisen. Memory allows us to find the significance of what was.

Part one: As it is

Objects mark the places where human bodies decompose.

Part two: The conflicts

Feeble monuments and symbols, stripped of their power through banality, that are left to commemorate the significance of individual lives and ritualistic beliefs rarely attain any of these meanings; in reality they create a landscape that serves as a reminder of the process of entropy on the human body and the emphasis this society places on material wealth. Memory is deceived by diștorted monuments left to represent things that are absent.

\section{Part three: Toward resolution}

A path is built through the landscape. Immersed in life, it brings us to a place of absence. It is the absence itself that allows

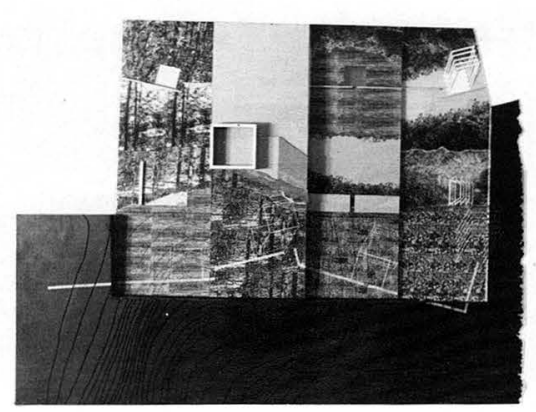

us to see the richness of the life that surrounds us. The path allows us to pause at places in which we are at once imminently aware of a specific natural context, but are deprived of the experience of it. The result is that we have a heightened awareness of the absent forces and can more completely appreciate the memory of their existence. Awareness is instigated by phenomonological experience instead of faltering symbolisms.

The path continues; cutting into the earth without warning and emerging at a place void of reference to the familiar. The columbarium is merely a fragment of a larger entity. Stored within an expanding structure, individual remains become part of a collective whole, a fragment of which is evident at this site. The columbarium offers no answers, but gives rise to many questions such as those of immortality and the significance of the individual to the whole.

A memory is instigated by observance of an absence and encouraged to expand when liberated from physical limitations.

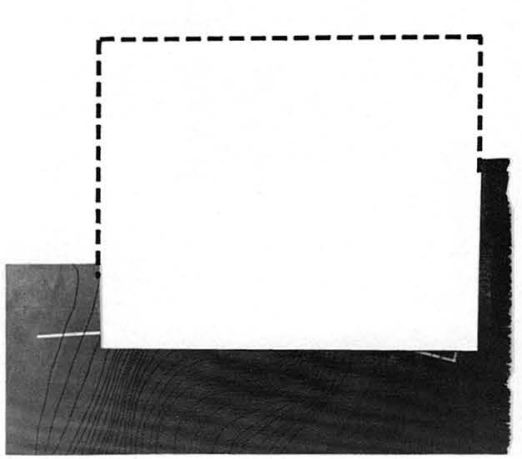

